\title{
Identifying objective quality attributes of functional foods
}

\author{
N.J. Astrini, T. Rakhmawati, S. Sumaedi and I.G.M.Y. Bakti \\ Research Center for Policy and Management of Science, Technology, and Innovation, Indonesian Institute of Sciences, \\ Gatot Subroto, Jakarta, Indonesia
}

Correspondence Author: nidy001@lipi.go.id

Received: 16 December 2019 / Accepted: 6 March 2020 / Published: 21 May 2020

(c) 2020 Codon Publications

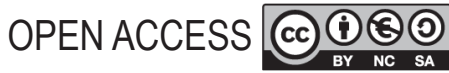

GENERAL REVIEW

\begin{abstract}
This study aims to identify objective quality attributes of functional foods based on literature reviews and proposing the future research agenda. There are not many articles that examined the objective quality of functional foods. This article aims to fill that gap: discussing objective quality attribute of functional foods based on the syntheses of previous studies. Previous research on objective quality of functional foods mostly came from the field of food science, and therefore applicable only to certain foods. Studies from the field of consumer behaviour/management mostly focused on perceived quality. This study used journals from three databases and utilised the term 'functional food' as the main keyword. Articles gathered were filtered based on their types and contents. There are two categories of objective quality found in literature. Firstly, objective quality related to the process, and secondly, objective quality related to the product itself. Both types are required to make accurate and marketable health claims of functional foods. Future research should try to empirically validate those objective quality attributes.
\end{abstract}

Keywords: health claim, safety, shelf-life, organoleptic, literature review

\section{Introduction}

The ancient recognition that foods provided health benefits encouraged the use of term 'functional food' (Sarkar, 2013). The term was first used in Japan in the late 1980s to represent additional nutrients that were detached from their recognised functions (Stanton et al., 2001). It has been well recognised that functional foods have positive impacts on individuals and public health. Studies concerning functional foods have established connections between the reduction of risks of diseases and healthcare costs (Shahidi, 2009). The market for functional food has grown considerably and was projected to touch US\$305.4 billion in 2020 (Bogue et al., 2017). The powers behind this massive growth were the developed countries' fascination towards superior performance and longevity (Lawrence and Germov, 2004) and the developing countries' intention to rein the spread of diseases caused by malnutrition (Asian Development Bank, 2000). The growth of functional foods was also fuelled by the relentless efforts of food companies for gaining competitive advantage (Nestle, 2002).
The 'push' from governments and food companies were well-situated among consumers with growing concerns about food-related health (Dixon et al., 2006). Current consumers perceive that functional foods provided an enhanced health benefit compared to traditional foods (e.g. Rojas-Rivas et al., 2019; Schnettler et al., 2015). This superiority was an objective characteristic demanded from all types of functional foods. However, it could not scientifically verify pre-purchase by consumers. They rely on health claims provided by the government, the marketers or both (Lu, 2015; Ovesen, 1999).

Regulators around the world have their own definitions of health claims. The European Union defined health claims as any claim that suggested or implied the relationship between a certain food substance and health (Lalor and Wall, 2011). The United States also used a similar definition. Japan, on the other hand, specified that any health claim made must be widely accepted by scientific experts and backed by sound evidence. In the management field, 'health claim' was known as one of the building blocks of quality (Gok and Ulu, 2018). 
Every product or service has two types of quality, which are objective and subjective quality. Objective quality refers to product-related characteristics that can be measured using technical instruments (Giacalone et al., 2016). Subjective quality, on the other hand, is consumers' perceptions (i.e. subjective for each person). A product would sell if consumers perceived its quality to be high. Perception or subjective quality has more weight than objective quality (Giacalone et al., 2016). However, in the drug and functional food industry, this inequality was reduced by regulations that control the objective quality of functional foods. In order to build a perception of health-enhancing food, companies are legally required to base it on a set of proven objective quality attributes. The economics of objective quality could be achieved if those objective qualities were recognised and accepted by consumers.

Unfortunately, no study has explored the attributes of functional foods' objective quality in spite of its importance. Previous studies on functional foods were dominated by three streams. The first stream was consumer behaviour. They mostly dealt with perceived quality (e.g. Brečić et al., 2014; Crofton et al., 2013; Davčik, 2013). The second stream was food science. They mostly focused on a specific functional food or its ingredients (e.g. Bekers et al., 2007, 2008; Busanello et al., 2019; Sharma and Ghoshal, 2018). Public policy was the third stream (e.g. Dixon et al., 2006; Lalor and Wall, 2011; Sadler, 1993). Previous articles predominantly discussed the regulations surrounding functional foods and health claims. Neither of the mentioned streams discussed the objective quality of functional foods in general. Therefore, this review aims to identify the objective quality of functional foods. It is expected that this review would be able to fill the gap in literature on the objective quality of functional foods. The findings could also be used in establishing regulations related to functional food by countries with a less developed functional food industry.

\section{Functional food}

Divergence in functional food's definitions has been often expressed in previous studies (e.g. Khan et al., 2014; Sarkar, 2013; Schnettler et al., 2015). The most referred definition was the one offered by Diplock et al. (1999):

Foods are called functional if it [they] demonstrated to affect beneficially one or more target functions in the body, beyond adequate nutritional effects in a way that is relevant to either improved state of health and well-being and/or reduction of risk of disease.

Compared with other descriptions regarding functional food, definition by Diplock et al. (1999) was somewhat general. For example, Bruce et al. (1999) stated the following:
A functional food is (or appears similar to) a conventional food. It is a part of a standard diet and is consumed on a regular basis, in normal quantities. It has proven health benefits that reduce the risk of specific chronic disease or beneficially affect target functions beyond its basic nutritional functions.

Another type of definition has surfaced. Labrecque and Charlebois (2011) argued that 'functional foods are the results of supplementing foodstuffs with nutraceuticals or a bioactive ingredient to deliver health benefits'.

All definitions agreed on a few points. Firstly, functional food is not a pill or a drug, it is a type of food, and it is supposed to be consumed as a part of normal diet. This was where Health Canada drew the line between functional food and nutraceutical. The later was defined as a commodity (or commodities) extracted from foods being used in pills or capsules (Shahidi, 2009). Secondly, to be called 'functional', food must have proven health benefits beyond basic nutrition. Albeit there are differences on the type of health benefits demanded by each definition; some asked for its ability to prevent particular chronic diseases (e.g. Doyon and Labrecque, 2008; Lara et al., 2018) and others required targeted functions, such as better performance or longevity (e.g. Dixon et al., 2006; Goldberg, 1994; Gray et al., 2003), but all insisted on functions beyond traditional foods.

The most prominent difference found in popular definitions was associated with the form of functional food. When the term was first coined in the 1980s, 'functional food' referred to foods that were added with nutraceuticals or bioactive component to improve health (Almeida et al., 2013; Dixon et al., 2006; Heasman and Mellentin, 2001). However, there have been articles stating that functional food could be both fresh and processed (e.g. Grajek et al., 2005; Markovina et al., 2011; Sarkar, 2007; Schreiner and Huykens-Keil, 2006; Verkerk et al., 2009). Grajek et al. (2005) included conventional foods that contain 'naturally occurring bioactive' and Sarkar (2018) even added the phrase 'known or unknown biologically active compounds'. Consequently, if this definition was adopted, the term 'functional food' would have a very indistinct barrier from conventional foods, since conventional food might have a biologically active compounds that are not recognised by the scientific community. This study decided to define functional food as 'a modified food that provides health benefits beyond basic nutrition.

The current functional foods are categorised into the following four types: fortified products, enhanced products, altered products and enhanced commodities (Bigliardi and Galati, 2013; Gok and Ulu, 2018; Kotilainen et al., 2006; Sloan, 2000; Spence, 2006). Fortified products mean foods that have been fortified with extra nutrients such as 
fruit juice fortified with vitamins. An enhanced product, on the other hand, is a type of food that contained new components not normally found in certain foods, such as fermented milk with probiotics. Bigliardi and Galati (2013) stated that an altered product is a food from which harmful components have been removed, reduced, or replaced by another with beneficial effects. The last type, enhanced commodities, refers to a type of food in which its natural components have been enhanced.

\section{Food quality}

Although health claims were one of the most important inherent characteristics of a functional food, it was not the most important factor that affected consumers' acceptance. Studies on functional food-related innovations and marketing have found that 'proven health' claim was only one of the variables that influenced consumers' perception about food quality.

As mentioned above, there are two types of food quality: perceived (i.e. subjective) and objective quality. Perceived quality denotes subjective evaluations of foods (Cardello, 1995; Giacalone et al., 2016; Lawless, 1995; SaenzNavajas et al., 2013). The perceptions were most likely to be unequal to objective characteristics. For example, objectively bananas contain vitamin, fibre, potassium and magnesium, regardless of their skin colours (Harvard T.H. Chan School of Public Health, n.d.). However, consumers still preferred bananas with no brown spots because they simply looked better.

Consumers' choice and behaviour were more affected by perceived rather than objective quality (La Barbera et al., 2016). A study conducted in Australia and New Zealand has found that $90 \%$ of consumers read the nutrition labels of packaged foods (Mhurchu and Gorton, 2007). However, the deciding factor was not the label but the consumers' perceptions of the label. The benefits perceived for consuming functional food, not the actual-lab-tested-effects, were the most important factors in consumers' acceptance (Rezai et al., 2017).

Even though the perceived quality has an outstanding effect, consumers still need to base their perceptions on something concrete (La Barbera et al., 2016). For example, meat quality. Consumer A perceived a block of meat as a high-quality steak when he or she saw a dense marbling pattern on it. However, Consumer B might consider it as a health risk. They have different perceptions in terms of meat quality, but they based their judgement on something objective, the marbling pattern shown on the meat. Marbling was the intramuscular fat that appeared like a marble pattern (Gotoh and Joo, 2016; Smith, 2016). The marbling was an example of objective quality; a set of product-oriented characteristics, such as the nutritional components, the uniform ripening colour and the measured acidity.

Objective quality, in terms of foods, means inherent characteristics of certain foods that could be measured technically. Since currently, there is no study that has focused on the objective quality of functional foods, this study is drawing cases from other types of foods to explain the objective quality. The first example is pineapple slices. Their objective quality indicators included the level of decay, browning index and overall acceptability (Gonzalez-Aguilar et al., 2004). Tristimulus reflectance colorimetry was used to assess the colour (Sapers and Douglas, 1998), and the firmness was measured using the maximum rupture force test (Gonzalez-Aguilar et al., 2004). The second example is the broccoli. The objective quality of broccoli is determined based on its shelf-life, colour and chlorophyll content (Jin et al., 2015). A 30\% yellowing on a broccoli floret was used as the proxy of shelf-life. Colour was assessed using a chromameter, and chlorophyll content was measured using the following formula: 'Milligrams of chlorophyll mass per gram of fresh weight'. The third example is poultry meat. The quality assessment of chicken breast has a different approach. In a particular study performed by Petracci et al. (2015), the objective quality of chicken meat was assessed not based on the presence of good characteristics but on the absence of defective characteristics. The objective quality of poultry meat was evaluated based on the absence of deep pectoral disease, pale, soft, exudative (PSE)-like white striping, and wooden breast (Petracci et al., 2015). In general, objective quality encompasses visual appearance, taste, texture and safety (free of diseases).

The above-mentioned examples showed that those foods have a set of clear objective quality indicators and measurements which could be used to separate or rank products based on their inherent characteristics. In the functional food category, there has not been a study that collected objective quality attributes or indicators which could be used to evaluate and compare products. Therefore, the current study's main purpose was to identify those objective quality attributes by conducting reviews of previous literature on functional foods.

\section{Methodology}

This study aimed to identify the attributes of objective quality of functional foods by reviewing previous literature. The inclusion/exclusion criteria are shown in Table 1. The ideal keywords would be 'functional foods' and 'objective quality', 'intrinsic quality', or 'objective cues'. However, based on research using three databases (Emerald Insight, ScienceDirect and Taylor \& Francis), the 
Table 1. Articles inclusion criteria.

\begin{tabular}{|c|c|c|c|}
\hline & Rationale & Included & Excluded \\
\hline Publication type & $\begin{array}{l}\text { The aim of this study is to review } \\
\text { research on functional foods. Thus, } \\
\text { articles chosen were research } \\
\text { articles only. }\end{array}$ & $\begin{array}{l}\text { Research article, case study, concep- } \\
\text { tual paper/literature review. }\end{array}$ & $\begin{array}{l}\text { Technical paper, secondary article, chapter } \\
\text { items, commentary/review of other articles. }\end{array}$ \\
\hline Peer-review & $\begin{array}{l}\text { Peer-reviewed process ensures the } \\
\text { validity and reliability of articles. }\end{array}$ & Peer-reviewed. & Non-peer-reviewed. \\
\hline $\begin{array}{l}\text { Quality of } \\
\text { journals }\end{array}$ & $\begin{array}{l}\text { Journal quality ensures the validity } \\
\text { and reliability of articles. } \\
\text { Journals were only taken from three } \\
\text { publishers because of the authors' } \\
\text { access limitation. }\end{array}$ & $\begin{array}{l}\text { Journals from three publishers: } \\
\text { Emerald Insight, ScienceDirect, } \\
\text { and Taylor \& Francis. }\end{array}$ & $\begin{array}{l}\text { Journals outside Emerald Insight, Science- } \\
\text { Direct, and Taylor \& Francis. }\end{array}$ \\
\hline Language & $\begin{array}{l}\text { The author(s) can only comprehend } \\
\text { texts in English. }\end{array}$ & Articles written or translated to English. & $\begin{array}{l}\text { Articles written in languages other than } \\
\text { English. }\end{array}$ \\
\hline Time frame & $\begin{array}{l}\text { The time frame was not defined } \\
\text { because this study aims to create a } \\
\text { broad comprehension of the topic and } \\
\text { not only the latest. }\end{array}$ & NA & NA \\
\hline Content & $\begin{array}{l}\text { This study aims to identify the } \\
\text { objective quality of functional food. } \\
\text { Thus, the article chosen were the } \\
\text { ones that focused on functional foods. }\end{array}$ & $\begin{array}{l}\text { (1) Articles on how to create or process } \\
\text { certain functional foods/ the production } \\
\text { side of functional food industry } \\
\text { (2) Articles on how to assess or } \\
\text { evaluate certain functional foods } \\
\text { (3) Articles concerning the consumers' } \\
\text { side of functional food industry } \\
\text { (4) Articles on functional food industry } \\
\text { in general } \\
\text { (5) Articles concerning the governments' } \\
\text { side of functional food industry }\end{array}$ & $\begin{array}{l}\text { (1) Articles that did not draw boundaries } \\
\text { between functional foods and nutraceuticals } \\
\text { (2) Articles that explored the potential func- } \\
\text { tional food properties contained in certain } \\
\text { foods (deciding whether certain food could } \\
\text { or could not be categorised as a functional } \\
\text { food) } \\
\text { (3) Articles that discussed the advantages } \\
\text { or disadvantages of certain methods to } \\
\text { characterise certain functional foods }\end{array}$ \\
\hline
\end{tabular}

results were thin. Therefore, two broad terms were used, 'functional food' and 'quality'. The articles were filtered further based on their types. The search on the three databases did not use year limitation, because we did not want to miss any groundwork that might be conducted decades ago but highly cited until now.

Using the Emerald Insight database, single terminology was used, 'functional foods' in 'anywhere' (any part of the text). This process yielded 230 unfiltered articles. Using the ScienceDirect database, the authors used 'functional food' as the keyword in 'title', and 'quality' as the keyword in 'title, abstract, keywords'. The result listed 35 research articles. Using Taylor \& Francis Online, the authors utilised the same method as the one used in for ScienceDirect. In all 92 articles were found. This study manually excluded secondary papers, technical papers, chapter items and commentary, and solely used research papers (including literature reviews). After manually filtering the articles based on their categories, the remaining were read to determine their relevance. This study excluded articles that did not focus on functional foods.

\section{Results and discussions}

\section{Articles' demographics}

This study gathered 357 articles from three databases (see Table 2), but after the filtering process based on publication type and content relevancy, the total number of research articles used in this study came down to 146. From selected 146 articles, this study identified several topics, such as consumer behaviour (marketing management), public policy, food science, health and medicine and others (i.e. biomedical and functional food industry) (see Figure 1). The three most popular topics are further elaborated in the next section.

Previous studies on functional foods are divided into three broad topics. The first topic is 'consumer behaviour and marketing management'. This is the most popular topic. In fact, consumer behaviour, in general, has always been a dominant area of social sciences (MacInnis and Folkes, 2009) because the society is continuously shifting and there have been observable differences based on 
Table 2. Total number of articles.

\begin{tabular}{lccc} 
& $\begin{array}{c}\text { The number of initial } \\
\text { articles }\end{array}$ & $\begin{array}{c}\text { Filtered based on } \\
\text { publication type }\end{array}$ & $\begin{array}{c}\text { Filtered based on } \\
\text { relevancy }\end{array}$ \\
\hline Emerald Insight & 230 & 193 & 96 \\
ScienceDirect & 77 & 35 & 18 \\
Taylor \& Francis & 92 & 92 & 32 \\
The total number of articles used in this study & & & 146 \\
\hline
\end{tabular}

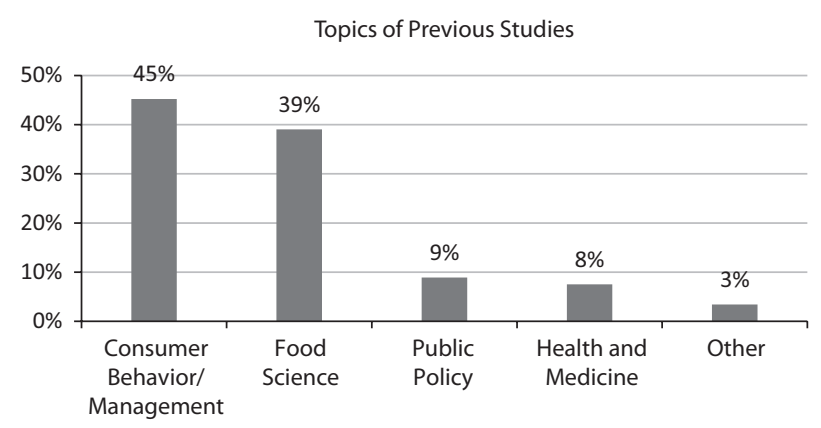

Figure 1. The categorisation of research topics in previous studies.

context which demanded a myriad of studies in the area. In the context of functional food industry, the interest on consumer behaviour might be built because even though the governments and the businesses were participating, consumer acceptance and growth of the functional food industry still heavily rely on consumers (Childs, 1997).

The four major topics in the consumer behaviour of functional foods were consumer awareness (e.g. Armstrong et al., 2005; Bazhan et al., 2017; Gok and Ulu, 2018), knowledge (e.g. Arens, 2018; Hasnah Hassan, 2011; Kljusuric et al., 2015; Lalor et al., 2011; Lu, 2015), perception (e.g. Badrie et al., 2007; Bazhan et al., 2017; Crofton et al., 2013) and consumer attitude (e.g. Kljusuric et al., 2015; Markovina et al., 2011; Rezai et al., 2017; Schnettler et al., 2015). The purposes of those studies are similar. However, those studies' underlying purposes were basically connate, to understand consumers' decisions regarding functional foods, and it was not uncommon for studies to coalesce those topics in a single article. This finding is aligned with a previous literaturere view on the topic of consumer behaviour in general by Peighambari et al. (2016).

Several notable findings were derived from previous studies. Firstly, there were many variables (i.e. independent, mediating and moderating) that have been proven to affect consumers' decision to either purchase or consume functional foods: perception, attitude, knowledge, trust, health-consciousness, to name a few. Secondly, people in countries such as Greece, Iran, Trinidad and Croatia, were found to be generally unfamiliar with the terms 'functional food' (or 'nutraceuticals' and 'designer foods'; Badrie et al., 2007; Bazhan et al., 2017; Christidis et al., 2011; Markovina et al., 2011). There were indications that consumers were confused, even though they have consumed functional foods before. The term was considered as a 'techno-jargon' that has not reached consumers (Bazhan et al., 2017). Thirdly, the intention or the decision-making process in terms of consuming or buying functional foods varied across age and gender. Females were more health-conscious and more likely to buy or consume functional foods compared to men (Armstrong et al., 2005; Bogue et al., 2017; Lalor et al., 2011) as well as early middle-aged people (Bhaskaran and Hardley, 2002; Čukelj et al., 2016; Krystallis et al., 2008; Schnettler et al., 2015).

The second most popular topic was food science (Figure 1; see also Table 3). Studies on this topic were dominated by the following three streams. Firstly, studies on the effect of a certain process towards a functional food's active compounds (e.g. Bekers et al., 2007, 2008; Ivanović et al., 2018; Lalel et al., 2017). Scientists generally question as to how production processes, storage and even fertilisation processes of certain functional foods' raw material could affect the efficacy and the shelf-life of functional foods. Secondly, studies on how to develop (or modify) a functional food (Agrahar-Murugkar et al., 2018; Ismail et al., 2018; Kia et al., 2018; Lara et al., 2018; Sanzana et al., 2011). Thirdly, studies on the health-related characteristics of functional foods. Different types of foods were investigated under this stream (Bouderbala and Bouchenak, 2016; Celiktas et al., 2010; Malav et al., 2015; Yousefi et al., 2018). Previous researchers either investigated active compounds or conducted trials on animals and humans.

The third broad topic is public policy. It has two major concerns, which were the effect of certain policy on functional food industry and regulations comparison between several countries (i.e. usually developed countries such as the United States, Japan, Australia, New Zealand and the European Union). The oldest publications (used in this study) on functional food regulation called for consumer protection so that the 'market does not run ahead of the science' (Sadler, 1993). The next batch of articles in the late 1990s argued that the concept of functional food at that moment was 'vague and malleable' and especially 
Table 3. Examples of foods examined in the previous studies.

\begin{tabular}{|c|c|c|}
\hline Category & Types of food (or its derivatives) & Author(s) \\
\hline \multirow[t]{6}{*}{ Fruits } & Mangifera pajang and Artocarpus odoratissimus & Bakar et al. (2010) \\
\hline & Palmyrah & Lalel et al. (2017) \\
\hline & Pomegranate & Ferrari et al. (2010) \\
\hline & & Çam et al. (2014) \\
\hline & Strawberry & Basu et al. (2014) \\
\hline & Carrot and watermelon & Mestry et al. (2011) \\
\hline \multirow[t]{5}{*}{ Vegetables } & Artichoke & Bekers et al. $(2007,2008)$ \\
\hline & Vegetable gourd & Devaki et al. (2015) \\
\hline & Swiss chard & Ivanović et al. (2018) \\
\hline & Microalgae & Sahni et al. (2019) \\
\hline & Aloe vera & Sanzana et al. (2011) \\
\hline \multirow[t]{3}{*}{ Poultry and meat } & Chicken egg & $\begin{array}{l}\text { Applegate (2000); Bhat et al. (2015); Surai and Sparks (2001); } \\
\text { Yousefi et al. (2018) }\end{array}$ \\
\hline & Quail egg & Sahin et al. (2008) \\
\hline & Meat & Olmedilla-Alonso et al. (2006) \\
\hline Fish & Fish & Tahergorabi et al. (2015) \\
\hline \multirow[t]{8}{*}{ Grains, beans and nuts } & Chickpea & Amaral et al. (2014) \\
\hline & Mung bean & Amaral et al. (2017) \\
\hline & Oat, maize, and soybean & Kaur et al. (2017) \\
\hline & Flaxseed & Hassan-Zadeh et al. (2008); Kumar et al. (2017) \\
\hline & Cereal & Lara et al. (2018) \\
\hline & Grains & Pasha et al. (2015) \\
\hline & Peanut & Bishi et al. (2015) \\
\hline & Nuts & Olmedilla-Alonso et al. (2006) \\
\hline \multirow[t]{2}{*}{ Dairy food } & Milk and yogurt & Ismail et al. (2018); Kia et al. (2018) \\
\hline & & Busanello et al. (2019); Saeed et al. (2013); Sarkar $(2013,2018)$ \\
\hline
\end{tabular}

unspecific for establishing any regulation (Glinsmann, 1997). In a 1998 study done by Childs (1997), it was found that Japan was the only country that had a set of regulations. Australia was reviewing it under the standardisation code, while Canada, the European Union and New Zealand had no regulation in place. The absence of specific and agreeable definition was probably the reason why up to this point, the 'functional food regulation' does not exist. Instead, countries formulated regulation on 'food with health claims.' The European Union's regulation regarding foods with health claims has been a popular research topic (e.g. Arens, 2018; Khedkar et al., 2016; Martinez and Siani, 2017). Previous studies have found that despite European Food Safety Authority's (EFSA) available guidelines (Pravst et al., 2018), translating regulatory requirements into scientific requirements remained a challenge for the functional food industry (Khedkar et al., 2017). Other countries were not free of confusion either.

\section{Functional foods' objective quality attributes}

One particular thing to be noted is that functional food is essentially a food (Bazhan et al., 2017; Diplock et al., 1999) that stands as a part of daily diet. Hence, the objective quality of functional food cannot be separated from the food type. A functional food carries the objective quality indicators of the vehicle, both sensory and non-sensory (see Table 4). For example, an enriched egg. Aside from assessing its functional properties, such as selenium, vitamin E, lutein and docosahexaenoic acid (DHA), evaluation of an egg's quality should also include albumen height, egg weight, yolk height, yolk diameter and the level of acidity. Functional foods' objective quality attributes are provided in Table 5.

\section{Product-oriented quality}

Has a proven health claim: The most cited functional food's objective quality is 'proven health claim. The claim ranges from reducing the risk of certain diseases (e.g. Doyon and Labrecque, 2008; Goetzke and Spiller, 2014), curing certain diseases (e.g. Bhaskaran and Hardley, 2002; Hunt, 1994), improving performance (e.g. Badrie et al., 2007; Dixon et al., 2006) and maintaining longevity (e.g. Aiello et al., 2016; Dixon et al., 2006). There were also claims on different types of nutrition contents.

Consumers cannot confirm this quality on their own; hence, they rely on two things. Firstly, the label provided by 
Table 4. Examples of foods' objective quality indicators.

\begin{tabular}{|c|c|c|c|c|c|}
\hline \multirow{2}{*}{$\begin{array}{l}\text { Types of } \\
\text { food }\end{array}$} & \multirow{2}{*}{$\begin{array}{l}\text { Carrierl } \\
\text { vehicle }\end{array}$} & \multicolumn{2}{|c|}{ Quality indicators of the carrier in general (A) } & \multicolumn{2}{|c|}{ Additional indicators of food as a functional food (B) } \\
\hline & & Non-Sensory & Sensory & Non-Sensory & Sensory \\
\hline \multirow[t]{15}{*}{ Fresh } & \multirow[t]{5}{*}{ Egg } & Albumen height & Appearance & Safe and potent dosage of: & Appearance \\
\hline & & Egg weight & Smell & Selenium & Smell \\
\hline & & Yolk height & Yolk shape & Vitamin E & Yolk shape \\
\hline & & Yolk diameter & Yolk consistency & Lutein & Yolk consistency \\
\hline & & Level of acidity & & DHA & \\
\hline & \multirow[t]{10}{*}{ Fish } & \multirow{6}{*}{$\begin{array}{l}\text { Adenosine triphosphate(ATP) } \\
\text { breakdown compounds } \\
\text { Trimethylamine (TMA), total } \\
\text { volatile base nitrogen (TVB-N), } \\
\text { thiobarbituric acid (TBA) and } \\
\text { formaldehyde }\end{array}$} & Skin colour & Safe and potent dosage of: & Skin colour \\
\hline & & & Presence of bloodspots & Eicosapentaenoic acid & Presence of bloodspots on \\
\hline & & & on gill cover & Docosahexaenoic acid & gill cover \\
\hline & & & Stiffness & Angiotensin-converting & Stiffness \\
\hline & & & Firmness of the belly & enzyme (ACE) inhibitors & Firmness of the belly \\
\hline & & & Smell & Phosphoenol pyruvate & Smell \\
\hline & & Ammonia & Eye's shape and clarity & (PEP) inhibitors & Eye's shape and clarity \\
\hline & & Volatiles & Gills' colour and smell & Taurine & Gills' colour and smell \\
\hline & & Biogenic amines & & (Antioxidants) & \\
\hline & & Total viable count & & Selenium & \\
\hline \multirow[t]{14}{*}{ Processed } & \multirow[t]{7}{*}{ Cereal } & \multirow{2}{*}{$\begin{array}{l}\text { Available cereal grains and } \\
\text { carbohydrates }(\mathrm{CHO})\end{array}$} & Moisture content & High fiber & Moisture content \\
\hline & & & Shape & Omega 3 & Shape \\
\hline & & \multirow{3}{*}{$\begin{array}{l}\text { Energy } \\
\text { Vitamins (thiamin, riboflavin, } \\
\text { niacin) }\end{array}$} & Colour & Cholesterol-reducing & Colour \\
\hline & & & Flavour & properties & Flavour \\
\hline & & & Taste & Antioxidant & Taste \\
\hline & & $\begin{array}{l}\text { Amino acids (lysine, threonine, } \\
\text { tryptophan) }\end{array}$ & Consistency & & Consistency \\
\hline & & $\begin{array}{l}\text { Protein quality (true digest- } \\
\text { ibility, biological value, net } \\
\text { protein, utilisation protein) }\end{array}$ & & & \\
\hline & \multirow[t]{7}{*}{ Cookies } & Dough texture & Colour & Safe and potent dosage of: & Colour \\
\hline & & Stickiness, adhesion and & Appearance & Phenolic & Appearance \\
\hline & & dough strength & Aroma & Flavonoid & Aroma \\
\hline & & Cookies texture & Hardness & Antioxidant activity & Hardness \\
\hline & & Moisture & Flavour & & Flavour \\
\hline & & Fat (proximate analysis) & Mouth feel & & Mouth feel \\
\hline & & Protein & After-taste & & After-taste \\
\hline
\end{tabular}

Source: Agrahar-Murugkar et al. (2018); Alasalvar et al. (2002); Crofton et al. (2013); Food and Agricultural Organisation (2017); Ribeiro et al. (2019); Sahin et al. (2008); Surai and Sparks (2001); Haard et al. (1999); Lara et al. (2018).

Note: The indicators listed in the table are by no means complete. Because the aim of this study is to capture the objective quality of functional foods in general, this article is not going to discuss the objective quality of each food in detail.

DHA, Docosahexaenoic acid.

functional food's producer (Armstrong et al., 2005; Bimbo et al., 2018; Childs, 1997; Shamal and Mohan, 2017). It is a general practice in the food industry to provide nutritional information on food packaging. At some places, it is mandatory to list sugar, salt and fat contents, the recommended intake, and the calories. The second factor on which a consumer relies upon is the information provided by the government (Foo et al., 2013; Hamlin and McNeill, 2016) such as the Health Star Rating (Australasian), Healthier Choice Symbol (Singapore) and FOSHU Symbol (Japan). Even though the effectiveness of these ratings or symbols was debatable, previous research has agreed that, to an extent, consumers considered these ratings as a proxy of proven health claims in their decision-making process.

In the functional food industry, businesses never made health claim categorisation and definition. Instead, different governments regulated it and each country has its own definition and categorisations (see for example Figure 2). Governments tend to shy away from the term 'functional food' and chose to call it 'foods with health claims'. Health claims are heavily regulated in developed countries. Generally, a health claim was a claim that 'expressly, or by implication characterizes, the relationship of any 
Table 5. Functional foods objective quality.

\begin{tabular}{|c|c|c|}
\hline Quality category & Quality attributes & Examples \\
\hline \multirow[t]{5}{*}{$\begin{array}{l}\text { Product-related } \\
\text { quality }\end{array}$} & Proven health claim & $\begin{array}{l}\text { Aiello et al. (2016); Badrie et al. (2007); Bhaskaran and Hardley (2002); } \\
\text { Dixon et al. (2006); Doyon and Labrecque (2008) }\end{array}$ \\
\hline & Organoleptically acceptable & Gray et al. (2003); Kljusuric et al. (2015); Kumar et al. (2017) \\
\hline & Safe & $\begin{array}{l}\text { Almeida et al. (2013); Anninou and Foxall (2017); Bazhan et al. (2017); } \\
\text { Hasler et al. (2001) }\end{array}$ \\
\hline & Suitable vehicle/carrier & Kraus (2015); Lalor et al. (2011); Uauy et al. (2002) \\
\hline & Reasonable shelf-life & Ferrari et al. (2010); Gaudette and Pickering (2013); Singh et al. (2015) \\
\hline \multirow[t]{3}{*}{$\begin{array}{l}\text { Process-related } \\
\text { quality }\end{array}$} & $\begin{array}{l}\text { Scientific-based production process (proxies: the } \\
\text { production process adhered to scientific findings) }\end{array}$ & Ferrari et al. (2010); Ismail et al. (2018); Zhao et al. (2005) \\
\hline & $\begin{array}{l}\text { Commercially viable production process (proxies: } \\
\text { price and availability) }\end{array}$ & $\begin{array}{l}\text { Bazhan et al. (2017); Brečić et al. (2014); Gok and Ulu (2018); Kljusuric } \\
\text { et al. (2015); Urala and Liisa (2003) }\end{array}$ \\
\hline & Standardised production process & Food Standards Australia New Zealand, 2007; The Ministry of Agriculture \\
\hline
\end{tabular}

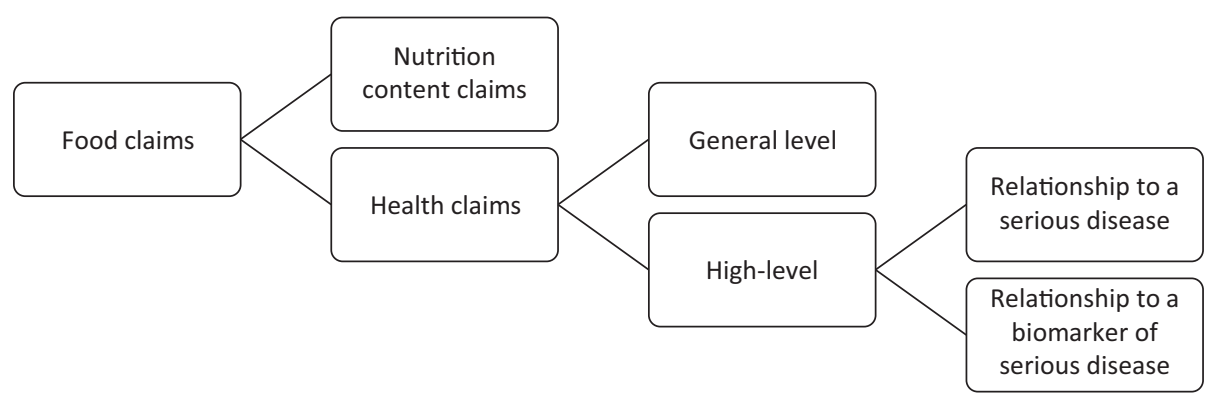

Figure 2. Health claims categorisation (Food Standards Australia New Zealand, 2016).

substance to a disease or health-related condition' (Lalor and Wall, 2011).

When it comes to product marketing and consumer acceptance, regulating health claims is essential because of consumer safety, which is very important. Governments must ensure that fear of certain diseases or degenerative conditions is not exploited commercially by functional food manufacturers using health claim labels. A health claim is something that consumers could not verify on their own. They might accept it, refuse it, or, very likely, misinterpret it (Markovina et al., 2011). Thus, the key here is not the type of claim but product's demand to be proved scientifically before it reaches consumers.

Health claims in the European Union were assessed by EFSA based on a high-standard scientific evaluation (Martinez and Siani, 2017). To prove health claims, EFSA mandated at least the following three things (Lensen et al., 2018):

1. Sufficient characterisation of bioactive substance

2. There must be a beneficial physiological effect

3. There must be an established, scientifically causal relationship between the substance and the physiological benefit
In Australia and New Zealand, the food standards are managed by the Food Standards Australia New Zealand (FSANZ). They have set the rules on how the food industry could make general health claims (e.g. maintain brain health) or high-level health claims (e.g. reduce the risk of heart attack; Tapsell, 2008). The substantiation of claims must be backed by scientific evidence, its relevance for the health of population, and worded correctly (Tapsell, 2008; Wellard-Cole et al., 2019). A previous study showed a $52 \%$ rate of successful substantiation of food health claims (Wellard-Cole et al., 2019).

In general, the scientific documentation needed to generate the most important objective quality indicator of functional foods (i.e. health claims) is classified into three categories: epidemiology, biological mechanisms and intervention trials (Ovesen, 1999). Epidemiological data used statistics to create an association between intake and certain diseases. Biological data were gathered using animal models that mimic the plausible mechanism of interaction between intake and the disease. The intervention trial was the highest form of documentation. It recorded data from 'human population intervention' (Ovesen, 1999, p. 811). 
Organoleptically acceptable: In spite of functional food's projected high growth rate (Gineikiene et al., 2017; Global Industry Analysts: Functional Food and Drinks, 2012), customers' acceptance, as a result of marketing process, has been extremely varied. Functional foods were highly accepted in the United States, European Union and Japan. However, previous studies have found that some market segments voiced concerns over the health claims and distrust towards manufacturers (Bazhan et al., 2017), and compared with organic foods, the health benefits of functional foods were often discounted (Gineikiene et al., 2017). Some consumers opined that alterations to foods had compromised their taste (Gray et al., 2003; Kljusuric et al., 2015; Kumar et al., 2017).

As mentioned before, functional food is essentially a food. For it to be digested properly, it must be good organoleptically, which means that human senses can accept and enjoy it. Consumers generally understood and even expected that the taste of functional foods would somehow be inferior compared to their traditional counterparts (Gray et al., 2003; Kljusuric et al., 2015; Kumar et al., 2017). However, at the very least, it must be decent.

There are two ways to assess organoleptic attributes. Firstly, by sensory analysis by panellists. For example, in a 2017 study by Lalel et al. (2017), they used 30 semitrained panellists to assess the appearance, crispiness, odour and flavour of five functional chips made out of cassava, wheat and palmyrah pulp. Another example is the analysis of colour, appearance, body and texture of goat milk mixed with tamr and honey (Rayeb milk). The product was organoleptically tested by 10 trained staff (Ismail et al., 2018). Sensory analysis was also done of omega-3 polyunsaturated fatty acid (PUFA)-fortified surimi seafood. The test was done by 79 panellists in terms of visual appeal, colour, aroma, texture, flavour and acceptability (Tahergorabi et al., 2015). The second way to evaluate an organoleptic attribute was through technical measurement. For example, assessing the firmness of butter using a cone penetrometer (Dixon and Parekh, 1980), evaluating food colours using a colorimeter (AgraharMurugkar et al., 2018; Biron et al., 2011; Çam et al., 2014; Ferrari et al., 2010; Lekshmi et al., 2019; Nunes et al., 2016; Zhao et al., 2005), calculating dough stickiness using Chen-Hosney stickiness cell, or cookies' brittleness with a three-point bending rig (Agrahar-Murugkar et al., 2018). Both ways to assess organoleptic attributes were considered as objective measures.

Suitable base-carrier/vehicle: The vehicle is the base food used to deliver additional functional properties. From the consumers' standpoint, it is about taste preferences (Kraus, 2015; Lalor et al., 2011). Preferences of certain products, such as milk or yogurt, could be exploited as effective delivery of health-enhancing compounds. From the governments' perspective, the delivery of functional food must consider coverage. The aim of governments, especially in developing countries, was to provide healthy food for as many people as possible. So, they tended to choose staple foods as the vehicles of functional ingredients (Mannar and Hurrell, 2018). From the scientists' perspective, it is about optimum delivery or the best vehicle for certain micro- or macronutrients and the inherent/naturally occurring functionality. The choice of food matrix and the source of bioactive compounds were extremely important because the biological impact of functional food is dependent on both. For example, iron fortification; it must consider the bioavailability of iron, the food matrix, and 'the balance of inhibitors and enhancers and total iron intake' (Uauy et al., 2002). Wheat has a higher percentage of iron absorption compared to maize-masa, making the former (in this context) a better carrier.

Safety: The issue of safety in terms of functional foods was the main concern (e.g. Almeida et al., 2013; Anninou and Foxall, 2017; Bazhan et al., 2017). Functional food is exhibited between food and medicine (Sarkar, 2007, 2018), and this fact has made the safety issue all the more important. Previous studies associated 'safety' with minimum (or no) side effects, but potent recommended daily intake. One of the previous articles argued another detail that the consumption of a particular functional food should not create significant interactions with prescription drugs (Hasler et al., 2001). Most of the articles in the Food Science category dedicated their studies to either characterising a potential functional food (e.g. Bhat et al., 2015; Saeed et al., 2013) or examining the level of certain compounds in functional foods to ensure its effectiveness in producing physiological benefits for consumers by testing them with live subjects (Ballali and Lanciai, 2012; Maringaneli and Jones, 2010). The se studies were conducted to ensure that functional foods were safe to consume in certain 'dosage', effective, and did not create an adverse effect.

Reasonable shelf-life: The case of shelf-life was somehow similar to the case of organoleptic attributes. Ideally, a long shelf-life is a desirable attribute when it comes to processed foods, but on the other hand, functional foods were at points required to be free of dangerous chemicals. A long shelf-life was hard to achieve naturally and both consumers and producers understood that in the context of functional foods or healthy foods, the lengths of shelf-life might be compromised. Previous studies also discussed natural ways to preserve or prolong the shelf-life of functional foods without adding dangerous chemicals or processing functional foods in a way that would significantly reduce its efficacy (Ferrari et al., 2010; Gaudette and Pickering, 2013; Singh et al., 2015). For example, a study done by Singh et al. (2015) focused 
on using Moringa Oleifera (drumstick tree) to preserve livestock-based functional foods. Another example was a high-pressure treatment to preserve natural anthocyanins in pomegranate juice (Ferrari et al., 2010).

\section{Process-oriented quality attributes}

The process-oriented quality was not mentioned explicitly or discussed in previous studies. However, their existence was countlessly implied in every article. There were three important process-oriented quality, which are the scientific-based production process, commercially viable process, and standardised food production process. All articles in the Food Science category were trying to find the health benefits of certain foods scientifically or to prove the causal relationship between functional ingredients or foods and physiological benefits. The production process must consider those studies to make sure that they generate products that possess sufficient beneficial compounds, confirming that the production process does not alter or diminish the efficacy of compound. On articles in the Public Policy category policy (e.g. Childs, 1997; Lalor and Wall, 2011), the scientific-based production process was also emphasised.

The second process-oriented quality attribute is a commercially viable process. This attribute was inferred from the rationale that functional foods must be accessible to the majority of people in a country. From the consumers' standpoint, this rationale necessitates affordable prices and easy access (i.e. available in many places). The quality indicators were often mentioned in articles in the Consumer Behaviour category (e.g. Bazhan et al., 2017; Brečić et al., 2014; Gok and Ulu, 2018; Kljusuric et al., 2015; Urala and Liisa, 2003). From the producers' perspective, this means that a quality product is the one that could be mass-produced at reasonable costs.

The third process-oriented quality attribute is a standardised food production process. This attribute was not specific for functional foods, but for processed foods in general. It was also not mentioned in the articles used in this study. However, to legally produce and distribute functional foods in a country or internationally, adherence to a specific standardised food production process is mandatory. The European Union's General Food Law, and Australia and New Zealand, for example, mandated the implementation of Hazard Analysis and Critical Control Points (HACCP) (Food Standards Australia New Zealand, 2007; The Ministry of Agriculture Nature and Food Quality of the Netherlands, 2005). A derivative of HACCP, ISO 22000 is also widely accepted as a norm for processed food production.

\section{Conclusions and the future research}

Functional food is a growing industry. Many studies have investigated almost every aspect of this industry, upstream (i.e. development of functional foods) until downstream (i.e. acceptance of functional foods by consumers). Studies on functional foods were dominated by three broad topics, which were consumer behaviour, food science and public policy. Articles on consumer behaviours encompassed subtopics, such as awareness, knowledge, perception and attitude, while articles on food science generally focused on the development or characterisation of certain functional foods. Articles on public policy discussed the effect of policy on the functional food industry as well as regulations' comparison across countries.

From the selected articles, this study found product- and process-related quality attributes, which were inherent characteristics of functional foods; variables which the absence of one of these attributes would make a food unqualified to be called functional food. Product-related quality attributes include the following: (1) Food has an enhanced health benefit, (2) it must be organoleptically acceptable, (3) safe, (4) delivered with suitable vehicle/ carrier, and (5) has a reasonable shelf-life. Process-related quality attributes are (1) a scientific-based production process, (2) a commercially viable production process, and (3) a standardised production process.

This study has identified the objective quality attributes of functional foods through a literature review using articles from three databases. However, the attributes are not validated empirically. Therefore, the first future research agenda is to validate the accuracy of those attributes from the perspective of governments, businesses and consumers as the major drivers of the functional food industry. Other objective quality attributes that have not been mentioned in this article could also be identified through validation process. This study has not determined detailed indicators from those objective quality attributes. Quality indicators are important to enable quality assessment of certain products or processes. Hence, the second future research agenda is to build more detailed indicators from attributes and create levels or ranks that could be used to measure the quality of functional foods objectively. As mentioned before, the growth of the functional food industry depends on consumers' acceptance, and subjective or perceived quality carries more weight than objective quality. Therefore, for the next consumer behaviour study, the third future research agenda is to pinpoint the objective quality that could best serve as a quality stimulus to persuade consumers.

\section{Acknowledgement}

All authors are main contributors. This study is funded by Insentif Riset Sistem Inovasi Nasional (National Innovation System Research Incentive [INSINAS]), Ministry of Research, Technology and Higher Education of the Republic of Indonesia. 


\section{Conflict of interests}

The authors declare no conflicts of interest with respect to research, authorship and/or publication of this article.

\section{Funding}

This research is funded by The Ministry of Research and Technology through the National Innovation System Research Incentive.

\section{Compliance with Ethical Standards}

This article followed all ethical standards for a research without direct contact with human or animal subjects.

\section{References}

Agrahar-Murugkar, D., Dwivedi, S., Dixit-Bajpaj, P. and Kumar, M., 2018. Effect of natural fortification with calcium and protein rich ingredients on texture, nutritional quality and sensory acceptance of cookies. Nutrition \& Food Science 48(5): 807-818. https://doi. org/10.1108/NFS-02-2018-004.1

Aiello, A., Accardi, G., Candore, G., Carruba, G., Davinelli, S., Passarino, G., Scapagnini, G., Vasto, S. and Caruso, C., 2016. Nutrigerontology: a key for achieving successful ageing and longevity. Immunity \& Ageing 13: 17. https://doi.org/10.1186/s12979-016-0071-2

Alasalvar, C., Garthwaite, T. and Oksuz, A., 2002. Practical evaluation of fish quality. In: Alasalvar, C. and Taylor, T. (eds.) Seafoods - Quality, technology and nutraceutical applications. Springer-Verlag, New York, NY, USA, pp. 17-31.

Almeida, F., de Paula, N. and Pessali, H., 2013. Institutional entrepreneurship in building the Brazilian market of functional yogurts. British Food Journal 116(1): 2-15. https://doi.org/10.1108/ BFJ-02-2012-0028

Amaral, A.L., Ferreira, E.S., Neves, V.A., and Demonte, A., 2014. Legumin from chickpea: hypolipidemic effect in the liver of hypercholesterolimic rats. Nutrition \& Food Science 44(5): 378-388. https://doi.org/10.1108/NFS-10-2013-0115

Amaral, A.L., Ferreira, E.S., Silva, M.A., Neves, V.A., and Demonte, A., 2017. The vicilin protein (Vigna radiata L.) of mung bean as a functional food: evidence of 'in vitro' hypocholesterolemic activity. Nutrition \& Food Science 47(6): 907-916. https://doi.org/10.1108/NFS-05-2017-0089

Anninou, I. and Foxall, G.R., 2017. Consumer decision-making for functional foods: insights from a qualitative study. Journal of Consumer Marketing 34(7): 552-565. https://doi.org/10.1108/ JCM-05-2016-1821

Applegate, E., 2000. Introduction: nutritional and functional roles of eggs in the diet. Journal of the American College of Nutrition 19(5): 495s-498s. https://doi.org/10.1080/07315724.2000.107189 71

Arens, U., 2018. Foods, nutrients and food ingredients with authorised EU health claims. In: Miller, K. (ed.) Woodhead Publishing Series in Food Science, Technology and Nutrition, Vol. 3. André Gerhard Wolff, Duxford, pp. 229-236.
Armstrong, G., Farley, H., Gray, J., and Durkin, M., 2005. Marketing health-enhancing foods: implications from the dairy sector. Marketing Intelligence \& Planning 23(7): 705-719. https://doi. org/10.1108/02634500510630221

Asian Development Bank, 2000. Manila Forum 2000: strategies to fortify essential foods in Asia and the Pacific. In: International Life Sciences Institute, and Micronutrient Initiative in November 2000, ADB Nutrition and Development Series No. 2. Manila, pp. $10-116$.

Badrie, N., Reid-Foster, S., Benny-Ollivierra, C., and Roberts, H., 2007. Exercise enthusiasts' perceptions and beliefs of functional foods in Trinidad, West Indies. Nutrition and Food Science 37(5): 345-357. https://doi.org/10.1108/00346650710828370

Bakar, M.F.A., Mohamed, M., Rahmat, A., Burr, S.A., and Fry, J.R., 2010. Cytotoxicity and polyphenol divresity in selected parts of Mangifera pajang and Artocarpus odoratissimus fruits. Nutrition \& Food Science 40(1): 29-38. https://doi. org/10.1108/00346651011015890

Ballali, S. and Lanciai, F., 2012. Functional food and diabetes: a natural way in diabetes prevention. International Journal of Food Sciences and Nutrition 63(S1): 51-61. https://doi.org/10.3109/0963 7486.2011.637487

Basu, A., Nguyen, A., Betts, N.M., and Lyons, T.J., 2014. Strawberry as a functional food: an evidence-based review. Food Science and Nutrition 54(6): 790-806. https://doi.org/10.1080/10408398.2011. 608174

Bazhan, M., Keshavarz-Mohammadi, N., Hosseini, H., and Kalantari, N., 2017. Consumers' awareness and perceptions regarding functional dairy products in Iran: a qualitative research. British Food Journal 119(2): 253-266. https://doi.org/10.1108/ BFJ-06-2016-0270

Bekers, M., Grube, M., Upite, D., Kaminska, E., Linde, R., Scherbaka, R., and Danilevich, A., 2007. Carbohydrates in Jerusalem artichoke powder suspension. Nutrition and Food Science 37(1): 42-49. https://doi.org/10.1108/00346650710726940

Bekers, M., Upite, D., Kaminska, E., Linde, R., Scherbaka, R., Danilevich, A., and Grube, M., 2008. Fermentation of Jerusalem artichoke by Zymomonas and Saccharomyces. Nutrition and Food Science 38(2): 128-135. https://doi.org/10.1108/00346650810863000

Bhaskaran, S. and Hardley, F., 2002. Buyer beliefs, attitudes and behaviour: foods with therepeutic claims. Journal of Consumer Marketing 19(7): 591-606. https://doi. org/10.1108/07363760210451410

Bhat, Z.F., Kumar, S. and Bhat, H.F., 2015. Bioactive peptides from egg: a review. Nutrition \& Food Science 45(2): 190-212. https:// doi.org/10.1108/NFS-10-2014-0088

Bigliardi, B. and Galati, F., 2013. Innovation trends in food industry: the case of functional foods. Trends in Food Science \& Technology 31: 118-129. https://doi.org/10.1016/j.tifs.2013.03.006

Bimbo, F., Bonanno, A., van Trijp, H., and Viscecchia, R., 2018. Body image dissatisfaction and health-enhancing food choices: a pilot study from a sample of Italian yogurt consumers. British Food Journal 120(12): 2778-2792. https://doi.org/10.1108/ BFJ-03-2018-0157

Biron, M., Farndale, E. and Paauwe, J., 2011. Performance management effectiveness: lessons from world-leading firms. 
The International Journal of Human Resource Management 22(6): 1294-1311. https://doi.org/10.1080/09585192.2011.559100

Bishi, S.K., Kumar, L., Mahatma, M.K., Khatediya, N., Chauhan, S.M., and Misra, J.B., 2015. Quality traits of Indian peanut cultivars and their utility as nutritional and functional food. Food Chemistry 167: 107-114. https://doi.org/10.1016/j.foodchem.2014.06.076

Bogue, J., Collins, O. and Troy, A.J., 2017. Developing New Functional Food and Nutraceutical Products. In: Bagchi, D. and Nair, S. (eds.) Market analysis and concept development of functional foods. Academic Press, Salt Lake City, UT, USA, pp. 29-45.

Bouderbala, S. and Bouchenak, M., 2016. Olive or salmon oils affect differently the storage and transport of fatty acids by VLDL in hypercholesterolemic rats fed different proteins. Nutrition \& Food Science 46(2): 190-203. https://doi.org/10.1108/ NFS-08-2015-0096

Brečić, R., Gorton, M. and Barjolle, D., 2014. Understanding variations in the consumption of functional foods - Evidence from Croatia. British Food Journal 116(4): 662-675. https://doi. org/10.1108/BFJ-05-2012-0133

Bruce, G., Schiffrin, E., Raniero, R., Mollet, B., Pfeifer, A., and Neeser, J.R., 1999. The development of functional foods: lessons from the gut. Trends in Biotechnology 17(12): 492-499. https:// doi.org/10.1016/S0167-7799(99)01380-3

Busanello, M., De Moraes Filho, M.L., Guergoletto, K.B., and Garcia, S., 2019. Optimization of the growth of Lactobacillus in skim milk added with green banana flour and determination functional properties. Nutrition and Food Science 49(2): 249-261. https:// doi.org/10.1108/NFS-03-2018-0098

Çam, M., Necattin, C.İ. and Fatma, E., 2014. Pomegranate peel phenolics: microencapsulation, storage stability and potential ingredient for functional food development. LWT-Food Science and Technology 55(1): 117-123. https://doi.org/10.1016/j. lwt.2013.09.011

Cardello, A.V., 1995. Food quality: relativity, context and consumer expectations. Food Quality and Preference 6(3): 163-170. https:// doi.org/10.1016/0950-3293(94)00039-X

Celiktas, O.Y., Isleten, M., Vardar-Sukan, F., and Cetin, E.O., 2010. In vitro release kinetics of pine bark extract enriched orange juice and the shelf stability. British Food Journal 112(10): 1063-1076. https://doi.org/10.1108/00070701011080203

Childs, N.M., 1997. Foods that help prevent disease: consumer attitudes and public policy implications. Journal of Consumer Marketing 14(6): 433-447.

Christidis, N., Tsoulfa, G., Varagunam, M., and Babatzimopoulou, M., 2011. A cross-sectional study of consumer awareness of functional foods in Thessaloniki, Greece. Nutrition \& Food Science 41(3): 165-174. https://doi.org/10.1108/00346651111132439

Crofton, E.C., Markey, A. and Scannell, A.G.M., 2013. Consumers' expectations and needs towards healthy cereal-based snacks. British Food Journal 115(8): 1130-1148. https://doi.org/10.1108/ BFJ-08-2011-0213

Čukelj, N., Putnik, P., Novotni, D., Ajredini, S., Voucko, B., and Curic, D., 2016. Market potential of lignans and omega-3 functional cookies. British Food Journal 118(10): 2420-2433. https://doi.org/10.1108/BFJ-03-2016-0117
Davčik, N.S., 2013. An empirical investigation of brand equity: drivers and their consequences. British Food Journal 115(9): 1342-1360. https://doi.org/10.1108/BFJ-01-2012-0005

Devaki, C.S., Wadikar, D. and Patki, P., 2015. Vegetable gourds Guards of human health: a critical appraisal. Nutrition \& Food Science 45(1): 125-144. https://doi.org/10.1108/ NFS-12-2013-0146

Diplock, A.T., Aggett, P.J., Ashwell, M., Bornet, F., Fern, E.B., and Roberfroid, M.B., 1999. Scientific concepts of functional foods in Europe: consensus document. British Journal of Nutrition 81(1): 1-27. https://doi.org/10.1017/S0007114599000471

Dixon, J.M., Hinde, S.J. and Banwell, C.L., 2006. Obesity, convenience and 'phood'. British Food Journal 108(8): 634-645. https:// doi.org/10.1108/00070700610682328

Dixon, B.D. and Parekh, J.V., 1980. Use of the cone penetrometer for testing the firmness of butter. Journal of Texture Studies 10(4): 421-434. https://doi.org/10.1111/j.1745-4603.1980.tb00868.x

Doyon, M. and Labrecque, J.A., 2008. Functional foods: a conceptual definition. British Food Journal 110(11): 1133-1149. https://doi. org/10.1108/00070700810918036

Ferrari, G., Maresca, P. and Ciccarone, R., 2010. The application of high hydrostatic pressure for the stabilization of functional foods: pomegranate juice. Journal of Food Engineering 100(2): 245-253. https://doi.org/10.1016/j.jfoodeng.2010.04.006

Foo, L.L., Vijaya, K., Sloan, R.A., and Ling, A., 2013. Obesity prevention and management: Singapore's experience. Obesity Reviews 14(2): 106-113. https://doi.org/10.1111/obr.12092

Huss, H.H., 1995. Food and Agricultural Organization, 2017. Assessment of fish quality. In: Quality and quality changes in fresh fish. FAO. http://www.fao.org/3/V7180E/V7180E09.htm

Food Standards Australia New Zealand, 2007. Food safety programs: a guide to standard 3.2.1 food safety programs. Food Standards, Canberra, Australia. Available at: http://www.foodstandards.gov. au/industry/safetystandards/documents/Guide321FoodSafetyPrograms-WEB.pdf.

Food Standards Australia New Zealand, 2016. Nutrition content claims and health claims. Food Standards, Canberra, Australia. San Jose, CA, Available at: http://www.foodstandards.gov.au/consumer/labelling/nutrition/Pages/default.aspx.

Gaudette, N.J. and Pickering, G.J., 2013. Modifying bitterness in functional food systems. Critical Reviews in Food Science and Nutrition 53(5): 464-481. https://doi.org/10.1080/10408398.201 0.542511

Giacalone, D., Fosgaard, T.R., Steen, I., and Münchow, M., 2016. 'Quality does not sell itself': divergence between 'objective' product quality. British Food Journal 118(10): 2462-2474. https://doi. org/10.1108/BFJ-03-2016-0127

Gineikiene, J., Kiudyte, J. and Degutis, M., 2017. Functional, organic or conventional? Food choices of health conscious and skeptical consumers. Baltic Journal of Management 12(2): 139-152. https://doi.org/10.1108/BJM-01-2016-0016

Glinsmann, W.H., 1997. Perspective on functional food development and commercialization. Journal of Nutraceuticals, Functional \& Medical Foods 1(2): 89-93. https://doi.org/10.1300/ J133v01n02_06 
Global Industry Analysts: Functional Food and Drinks, 2012. San Jose, CA. Available at: http://www.strategyr.com/Functional_ Foods_And_Drinks_Market_Report.asp.

Goetzke, B.I. and Spiller, A., 2014. Health-improving lifestyles of organic and functional food consumers. British Food Journal 116(3): 510-526. https://doi.org/10.1108/BFJ-03-2012-0073

Gok, I. and Ulu, E.K., 2018. Functional foods in Turkey: marketing, consumer awareness and regulatory aspects. Nutrition and Food Science 49(4): 668-686. https://doi.org/10.1108/NFS-07-2018-0198

Goldberg, I., 1994. Functional foods: designer foods, pharma foods, and nutraceuticals. Chapman and Hall, London.

Gonzalez-Aguilar, G.A., Ruiz-Cruz, S., Cruz-Valenzuela, R., Rodriguez-Felix, A., and Wang, C.Y., 2004. Physiological and quality changes of fresh-cut pineapple treated with antibrowning agents. Lebensmittel-Wissenschaft und-Technologie37(3): 369-376. https://doi.org/10.1016/j.lwt.2003.10.007

Gotoh, T. and Joo, S-.T., 2016. Characteristics and health benefit of highly marbled Wagyu and Hanwoo beef. Korean Journal for Food Science of Animal Resources 36(6): 709-718. https://doi. org/10.5851/kosfa.2016.36.6.709

Grajek, W., Olejnik, A. and Sip, A., 2005. Probiotics, prebiotics, and antioxidants as functional foods. Acta Biochemica Polonica 52(3): 665-671. https://doi.org/10.18388/abp.2005_3428

Gray, J., Armstrong, G. and Farley, H., 2003. Opportunities and constraints in the functional food market. Nutrition \& Food Science 33(5): 213-218. https://doi.org/10.1108/00346650310499730

Haard, N., Odunfa, S.A., Lee, C-H., Quinterro-Ramirez, R., Lorence-Quiñones, A., and Wacher-Radarte, C., 1999. Nutritional qualities of cereals. In: Fermented cereals: a global perspective. Food and Agriculture Organization of the United Nations, Rome, Italy.

Hamlin, R. and McNeill, L., 2016. Does the Australasian 'Health Star Rating' front of pack nutritional label system work? Nutrients 8(6): 327-341. https://doi.org/10.3390/nu8060327

Harvard T.H. Chan School of Public Health, n.d.. Bananas. Available at: https://www.hsph.harvard.edu/nutritionsource/food-features/ bananas/.

Hasler, C., Moag-Stahlberg, A., Webb, D., and Hudnall, M., 2001. How to evaluate the safety, efficacy, and quality of functional foods and their ingredients. Journal of the American Dietetic Association 101(7): 733-736. https://doi.org/10.1016/S0002-8223(01)00180-8

Hasnah Hassan, S., 2011. Consumption of functional food model for Malay Muslims in Malaysia. Journal of Islamic Marketing 2(2): 104-124. https://doi.org/10.1108/17590831111139839

Hassan-Zadeh, A., Sahari, M.A. and Barzegar, M., 2008. Optimization of the omega-3 extraction as a functional food from flaxseed. International Journal of Food Sciences and Nutrition 59(6): 526-534. https://doi.org/10.1080/09637480701565935

Heasman, M. and Mellentin, J., 2001. The functional food revolution: healthy people, healthy profits. London: Earthscan, pp 1-75. ISBN 978-1-85383-687-9.

Hunt, J.R., 1994. Nutritional products for specific health benefits foods, pharmaceuticals, or something in-between? Journal of the American Dietetic Association 94(2): 151-153. https://doi. org/10.1016/0002-8223(94)90238-0
Ismail, M., Hamad, M. and Elraghy, E.M., 2018. Quality of Rayeb milk fortified with tamrn and honey. British Food Journal 120(2): 499-514. https://doi.org/10.1108/BFJ-04-2017-0259

Ivanović, L., Milašević, I., Topalović, A. Đurović, D., Mugoša, B., Knežević, M.,and Vrvić, M., 2018. Nutritional and phytochemical content of Swiss chard from Montenegro, under different fertilization and irrigation treatments. British Food Journal 121(2): 411-425. https://doi.org/10.1108/BFJ-03-2018-0142

Jin, P., Yao, D., Xu, F. Wang, H., and Zheng, Y., 2015. Effect of light on quality and bioactive compounds in postharvest broccoli florets. Food Chemistry 172: 705-709. https://doi.org/10.1016/j. foodchem.2014.09.134

Kaur, J., Kaur, A. and Singh, J., 2017. Nutritional evaluation and utilization of composite whole flours for making functional cookies rich in $\beta$-glucan and isoflavones. British Food Journal 119(4): 909-920. https://doi.org/10.1108/BFJ-07-2016-0308

Khan, R.S., Grigor, J.V., Win, A.G., and Boland, M., 2014. Differentiating aspects of product innovation processes in the food industry: an exploratory study on New Zealand. British Food Journal 116(8): 1346-1368. https://doi.org/10.1108/BFJ-04-2013-0094.

Khedkar, S., Broring, S. and Ciliberti, S., 2017. Exploring the nutrition and health claims regulation (EC) No. 1924/2006: what is the impact on innovation in the EU food sector? International Journal of Food Sciences and Nutrition 68(1): 10-17. https://doi.org/10.1 080/09637486.2016.1212818

Khedkar, S., Ciliberti, S. and Broring, S., 2016. The EU health claims regulation: implications for innovation in the EU food sector. British Food Journal 118(11): 2647-2665. https://doi.org/10.1108/ BFJ-01-2016-0021

Kia, E.M., Ghasempour, Z., Ghanbari, S., Pirmohammadi, R., and Ehsani, A., 2018. Development of probiotic yogurt by incorporation of milk protein concentrate (MPC) and microencapsulated Lactobacillus paracasei in gellan caseinate. British Food Journal 120(7): 1516-1528. https://doi.org/10.1108/BFJ-12-2017-0668

Kljusuric, J.G., Cacic, J., Misir, A., and Čačić, D., 2015. Geographical region as a factor influencing consumers' perception of functional food-case of Croatia. British Food Journal 117(3): 1017-1031. https://doi.org/10.1108/BFJ-12-2013-0282

Kotilainen, L., Rajalahti, R., Ragasa, C., and Eija, P., 2006. Health enhancing foods: opportunities for strengthening the sector in developing countries. World Bank, Washington, DC.

Kraus, A., 2015. Factors influencing the decisions to buy and consume functional food. British Food Journal 117(6): 1622-1636. https://doi.org/10.1108/BFJ-08-2014-0301

Krystallis, A., Maglaras, G. and Mamalis, S., 2008. Motivations and cognitive structures of consumers in their purchasing of functional foods. Food Quality and Preference 19(6): 525-538. https:// doi.org/10.1016/j.foodqual.2007.12.005

Kumar, S., Mendiratta, S.K., Agrawal, R.K., Sharma, H., and Kumar, R.R., 2017. Quality evaluation of mutton nuggets incorporated with optimized level of flaxseed flour. Nutrition and Food Science 47(1): 67-77. https://doi.org/10.1108/NFS-07-2015-0081

La Barbera,F., Amato, A. and Sannino, G., 2016. Understanding consumers' intention and behaviour towards functionalised food: the role of knowledge and food technology neophobia. 
British Food Journal 118(4): 885-895. https://doi.org/10.1108/ BFJ-10-2015-0354

Labrecque, J. and Charlebois, S., 2011. Functional foods: an empirical study on perceived health benefits in relation to pre-purchase intentions. Nutrition and Food Science 41(5): 308-318. https:// doi.org/10.1108/00346651111170905

Lalel, H.J., Mahayasa, N.W., Hidayah, Z, and Kartiwan, KW., 2017. Effort to explore the potential use of palmyrah fruit for functional food. British Food Journal 119(10): 2253-2266. https://doi. org/10.1108/BFJ-10-2016-0507

Lalor, F. and Wall, P.G., 2011. Health claims regulations. British Food Journal 113(2): 298-313. https://doi.org/10.1108/ 00070701111105358

Lalor, F., Kennedy, J. and Wall, P.G., 2011. Impact of nutrition knowledge on behaviour towards health claims on foodstuffs. British Food Journal 113(6): 753-765. https://doi. org/10.1108/00070701111140098

Lara, N.S., Sousa, M.M.M., Gandra, F.P.P., de Angelis-Pereira, M.C., de Deus Souza Carneiro, J., and Pereira, R.G.F.A., 2018. Development of a functional food bar containing coffee. British Food Journal. 121(2): 451-453. https://doi.org/10.1108/BFJ-03-2018-0135

Lawless, H.T., 1995. Dimensions of sensory quality: a critique. Food Quality and Preference 6(3): 191-199. https://doi. org/10.1016/0950-3293(94)00023-O

Lawrence, M. and Germov, J., 2004. Future food: the politics of functional foods and health claims. In: Germov, J. and Williams, L. (eds.) A sociology of food and nutrition. The social appetite. Oxford University Press, Melbourne, Australia, pp. 119-147.

Lekshmi, R.G.K., Rahima, M., Chatterjee, N.S., Tejpal, C.S., Anas, K.K., Vishnu, K.V., Sarika, K., Asha, K.K., Anandan, R., and Suseela, M., 2019. Chitosan - whey protein as efficient delivery system for squalene: characterization and functional food application. International Journal of Biological Macromolecules 135: 855-863. https://doi.org/10.1016/j.ijbiomac.2019.05.153

Lensen, K., Bast, A. and de Boer, A., 2018. Clarifying the health claim assessment procedure of EFSA will benefit functional food innovation. Journal of Functional Foods 47: 386-396. https://doi. org/10.1016/j.jff.2018.05.047

$\mathrm{Lu}, \mathrm{J} ., 2015$. The effect of perceived carrier-ingredient fit on purchase intention of functional food moderated by nutrition knowledge and health claim. British Food Journal 117(7): 1872-1885. https:// doi.org/10.1108/BFJ-11-2014-0372

MacInnis, D. and Folkes, V., 2009. The disciplinary status of consumer bahavior: a sociology of science perspective on key controversies. Journal of Consumer Research 36(6): 899-914. https:// doi.org/10.1086/644610

Malav, O.P., Sharma, B.D., Kumar, R.R., Talukder, S., Ahmed, S.R., and Irshad, A., 2015. Antioxidant potential and quality characteristics of functional mutton patties incorporated with cabbage powder. Nutrition \& Food Science 45(4): 542-563. https://doi. org/10.1108/NFS-03-2015-0019

Mannar, M.G.V. and Hurrell, R. (eds.), 2018. Food fortification in a globalized world. $1^{\text {st }}$ edition. Academic Press, Salt Lake City, UT, Cambridge, MA, USA.
Maringaneli, C. and Jones, J.P., 2010. Plant-sterols, marine-derived omega-3 fatty acids and other functional ingredients: a new frontier for treating hyperlipidemia. Nutrition \& Metabolism 7(1): 76. https://doi.org/10.1186/1743-7075-7-76

Markovina, J., Čačić, J., Kljusurić, G.J., and Kovacic, D., 2011. Young consumers' perception of functional foods in Croatia. British Food Journal113(1):7-16.https://doi.org/10.1108/00070701111097303

Martinez, S.V. and Siani, A., 2017. Health claims made on food in the EU: the edge between scientific knowledge and regulatory requirements. Trends in Food Science \& Technology 69(B): 315-323. https://doi.org/10.1016/j.tifs.2017.01.005

Mestry, A.P., Mujumdar, A.S. and Thorat, B.N., 2011. Optimization of spray drying of an innovative functional food: fermented mixed juice of carrot and watermelon. Drying Technology: An International Journal 29(10): 1121-1131. https://doi.org/10.1080/07373 937.2011 .566968

Mhurchu, C.N. and Gorton, D., 2007. Nutrition labels and claims in New Zealand and Australia: a review of use and understanding. Australian and New Zealand Journal of Public Health 31(2): 105-112. https://doi.org/10.1111/j.1753-64.05.2007.00026.x

Nestle, M., 2002. Food politics. University of California Press, Berkeley, CA, USA.

Nunes, M.A., Costa, A., Berreira, J., Vinha, A.F., Alves, R.C., Rocha, A., and Oliveira, B.P.P., 2016. How functional foods endure throughout the shelf storage? Effects of packing materials and formulation on the quality parameters and bioactivity of smoothies. LWT-Food Science and Technology 65: 70-78. https://doi. org/10.1016/j.lwt.2015.07.061

Olmedilla-Alonso, B., Granado-Lorencio, F., Herrero-Barbudo, C., Blanco-Navarro, I., 2006. Nutritional approach for designing meatbased functional food products with nuts. Food Science and Nutrition 46(7): 537-542. https://doi.org/10.1080/10408390500295508 Ovesen, L., 1999. Functional foods: some relevant considerations? British Food Journal 101(10): 809-817. https://doi. org/10.1108/00070709910293715

Pasha, I., Hussain, S., Khan, M.I., and Akram, N., 2015. Utilization of processed Vigna mungo L. flour in cookies. Nutrition \& Food Science 45(6): 883-894. https://doi.org/10.1108/NFS-05-2015-0064

Peighambari, K., Sattari, S., Kordestani, A. and Oghazi, P., 2016. Consumer behavior research: a synthesis of the recent literature. Sage Open 6(2): 1-9. https://doi.org/10.1177\%2F2158244016645638

Petracci, M., Mudalal, S., Soglia, F., and Cavani, C., 2015. Meat quality in fast-growing broiler chickens. World's Poultry Science Journal 71(2): 363-374. https://doi.org/10.1017/S0043933915000367

Pravst, I., Kusar, A., Zmitek, K., Miklavec, K., Lavriša, Z., Lähteenmäki, L., Kulikovskaja, V., Malcolm, R., Hodkins, C., and Raats, M., 2018. Recommendations for successful substantiation of new health claims in the European Union. Trends in Food Science \& Technology 71: 259-263. https://doi.org/10.1016/j. tifs.2017.10.015

Rezai, G., Teng, P.K., Shamsudin, M.N., Mohamed, Z., and Stanton, J.L., 2017. Effect of perceptual differences on consumer purchase intention of natural functional food. Journal of Agribusiness in Developing and Emerging Economics 7(2): 153-173. https://doi.org/10.1108/JADEE-02-2015-0014 
Ribeiro, A.R., Altintzoglou, T., Mendes, J., Nunes, M.L., Dinis, M.T., and Dias, J., 2019. Farmed fish as a functional food: perception of fish fortification and the influence of origin - insights from Portugal. Aquaculture 501: 22-31. https://doi. org/10.1016/j.aquaculture.2018.11.002

Rojas-Rivas, E., Espinoza-Ortega, A., Thomé-Ortiz, H., and Moctezuma-Pérez, S., 2019.Consumers' perception of amaranth in Mexico. British Food Journal. 1190-1202. https://doi. org/10.1108/bfj-05-2018-0334.

Sadler, M., 1993. Functional foods: foods of the future. Nutrition \& Food Science 93(4): 11-13. https://doi.org/10.1108/ EUM0000000000993

Saeed, M., Anjum, F.M., Khan, M.R., Khan, M.I., and Nadeem, M., 2013. Isolation, characterization and utilization of starter cultures for the development of wheyghurt drink. British Food Journal 115(8): 1169-1186. https://doi.org/10.1108/BFJ-10-2011-0274

Saenz-Navajas, M., Ballester, J., Pecher, C., Peyron, D., and Valentin, D., 2013. Sensory drivers of intrinsic quality of red wines: effect of culture and level of expertise. Food Research International 54(2): 1506-1518. https://doi.org/10.1016/j. foodres.2013.09.048

Sahin, N., Akdemir, F., Orhan, C., Kucuk, O., Hayirli, A., and Sahin, K., 2008. Lycopene-enriched quail egg as functional food for humans. Food Research International 41(3): 295-300. https://doi. org/10.1016/j.foodres.2007.12.006

Sahni, P., Aggarwal, P., Sharma, S., and Singh, B., 2019. Nuances of microalgal technology in food and nutraceuticals: a review. $\mathrm{Nu}$ trition \& Food Science 49(5): 866-885. https://doi.org/10.1108/ NFS-01-2019-0008

Sanzana, S., Grasa, M.L. and Vidal-Brotóns, D., 2011. Functional foods enriched in Aloe vera. Effects of vacuum impregnation and temperature on the respiration rate and the respiratory quotient of some vegetables. Procedia Food Science 1: 1528-1533.

Sapers, G.M. and Douglas, J.F.W., 1998. Measurement of enzymatic browning at cut surfaces and in juice of raw apple and pear fruits. Journal of Food Science 63: 1285-1261.

Sarkar, S., 2007. Functional foods as self-care and complementary medicine. Nutrition and Food Science 37(3): 160-167. https://doi. org/10.1108/00346650710749053

Sarkar, S., 2013. Probiotics as functional foods: documented health benefits. Nutrition and Food Science 43(2): 107-115. https://doi. org/10.1108/00346651311313445

Sarkar, S., 2018. Potentiality of probiotic yoghurt as a functional food - a review. Nutrition and Food Science 49(2): 182-202. https://doi.org/10.1108/NFS-05-2018-0139

Schnettler, B., Miranda, H., Lobos, G., Sepulveda, J., Orellana, L., Mora, M., and Grunert, K., 2015. Willingness to purchase functional foods according to their benefits: consumer profiles in Southern Chile. British Food Journal 117(5): 1453-1473. https:// doi.org/10.1108/BFJ-07-2014-0273

Schreiner, M. and Huykens-Keil, S., 2006. Phytochemicals in fruit and vegetables: health promotion and post-harvest elicitors. Critical Reviews in Plant Sciences 25(3): 267-278. https://doi. org/10.1080/07352680600671661
Shahidi, F., 2009. Nutraceuticals and functional foods: whole versus processed foods. Trends in Food Science \& Technology 20(9): 376-387. https://doi.org/10.1016/j.tifs.2008.08.004

Shamal, S. and Mohan, B.C., 2017. Consumer behaviour in fortified food choice decisions in India. Nutrition and Food Science 47(2): 229-239. https://doi.org/10.1108/NFS-05-2016-0065

Sharma, R. and Ghoshal, G., 2018. Nutrition \& Food Science article information. Nutrition \& Food Science 48(5): 764-779. Available at: http://www.emeraldinsight.com/doi/pdfplus/10.1108/ NFS-12-2014-0097.

Singh, T.P., Singh, P. and Kumar, P., 2015. Drumstick (Moringa oleifera) as a food additive in livestock products. Nutrition \& Food Science 45(3): 423-432. https://doi.org/10.1108/NFS-02-2015-0018

Sloan, A.E., 2000. The top ten functional food trends. Food Technology 54: 33-62.

Smith, S., 2016. Marbling and its nutritional impact on risk factors for cardiovascular disease. Korean Journal for Food Science of Animal Resources 36(4): 435-444. https://doi.org/10.5851/ kosfa.2016.36.4.435

Spence, J.T., 2006. Challenges related to the composition of functional foods. Journal of Food Composition and Analysis 19: S4-S6. https://doi.org/10.1016/j.jfca.2005.11.007

Stanton, C., Gardiner, G., Meehan, H., Collins, K., Fitzgerald, G., Lynch, P.B., and Ross, R.P., 2001. Market potential for probiotics. The American Journal of Clinical Nutrition 73(2): 476-483. https://doi.org/10.1093/ajcn/73.2.476s

Surai, P.F. and Sparks, N.H., 2001. Designer eggs: from improvement of egg composition to functional food. Trends in Food Science \& Technology 12(1): 7-16. https://doi.org/10.1016/ S0924-2244(01)00048-6

Tahergorabi, R., Matak, K.E. and Jaczynski, J., 2015. Fish protein isolate: development of functional foods with nutraceutical ingredients. Journal of Functional Foods 18: 746-756. https://doi. org/10.1016/j.jff.2014.05.006

Tapsell, L., 2008. Evidence for health claims: a perspective from the Australia-New Zealand region. The Journal of Nutrition 138(6): 1206s-1209s. https://doi.org/10.1093/jn/138.6.1206S

The Ministry of Agriculture Nature and Food Quality of the Netherlands, 2005. European food safety control systems: new perspectives on a harmonized legal basis. Available at: http://www.fao. org/3/y5871e/y5871e0l.htm.

Uauy, R., Hertrampf, E. and Reddy, M., 2002. Iron fortification of foods: overcoming technical and practical barriers. The Journal of Nutrition 132(4): 849s-852s. https://doi.org/10.1093/jn/132.4.849S

Urala, N. and Liisa, L., 2003. Reasons behind consumers' functional food choices. Nutrition \& Food Science 33(4): 148-158. https:// doi.org/10.1108/00346650310488499

Verkerk, R.,Schreiner, M., Krumbein, A., Ciska, E., Holst, B., Rowland, I., de Schrijver, R., Hansen, M., Gerhauser, C., Mithen, R., and Dekker, M., 2009. Glucosinolates in Brassica vegetables - the influence of the food supply chain on intake, bioavailability and human health. Molecular Nutrition \& Food Research 53(Suppl. (S2)): S219-S265. https://doi.org/10.1002/mnfr.200800065

Verkerk, R., Schreiner, M., Krumbein, A., Ciska, E., Holst, B., Rowland, I., de Schrijver, R., Hansen, M., Gerhauser, C., Mithen, R., 
and Dekker, M., 2019. How effective is food industry selfsubstantiation of food-health relationships underpinning health claims on food labels in Australia? Public Health Nutrition 22(9): 1686-1695. https://doi.org/10.1017/S1368980018004081

Yousefi, M., Khorsidian, N. and Hosseini, H., 2018. An overview of the functionality of inulin in meat and poultry products.
Nutrition \& Food Science 48(5): 819-835. https://doi.org/10.1108/ NFS-11-2017-0253

Zhao, Y., Park, S., Leonard, SW., and Traber, M.G., 2005. Vitamin E and mineral fortification in fresh-cut apples (Fuji) using vacuum impregnation. Nutrition \& Food Science 35(6): 393-402. https:// doi.org/10.1108/00346650510633792 